\title{
Comparison of the Level of Robotisation in Poland and Selected Countries, including Social and Economic Factors
}

\author{
Miroslaw Smieszek ${ }^{1}$, Pawel Dobrzanski ${ }^{2}$, \\ Magdalena Dobrzanska ${ }^{1}$
}

${ }^{1}$ Department of Quantitative Methods, Rzeszow University of Technology, Poland,msmieszk@prz.edu.pl,md@prz.edu.pl

${ }^{2}$ Department of Computer Engineering in Management, Rzeszow University of Technology, Poland,pd@ @rz.edu.pl

\begin{abstract}
Two opposing tendencies are observable in the field of industrial production in economically developed countries. From the perspective of the management staff, for whom economic effects are paramount, the most important are increased work efficiency and reduced cost of production. Such actions are intended to provide an appropriate competitive position for the company. From the standpoint of the employees, aware of their growing position on the labour market and their value, the most important are suitable working conditions and adequate compensation. These opposing tendencies can be reconciled by the widespread automation and robotisation of the production processes. This requires substantial investment and, considering the growing costs of labour, can provide an increase in efficiency and a reduction in the costs of production. Growth in robotisation and automation are also necessary due to the shrinking labour resources. This paper is intended to analyse the level of robotisation in selected countries, and to investigate the relations between labour costs and the degree of robot utilisation. The final part of the paper characterises the condition of Polish industry from the perspective of robotisation, based on a more in-depth analysis of selected factors. On this basis, the directions are outlined for the necessary changes to achieve further growth and approach the levels observed in European Union countries.
\end{abstract}

Keywords: robotisation; industrial production; efficiency; labour costs; labour market

\section{Introduction}

Modern manufacturing companies strive to effectively manage their resources [17, 20]. Within its operations, a company has to reconcile many opposing tendencies. Employees expect growing compensation and improving working conditions, while the employer desires lower production costs and improved efficiency. Robotisation is an element that can contribute to satisfying the needs of both 
employees and employers. It provides businesses with new opportunities $[1,11$, 24], including increased production capacity [22], reduced downtime, and improved efficiency, quality and work safety $[12,7]$.

Industrial robots and manipulators [3] are some of the ways to automate the production and support processes [10], by performing specific actions without human participation. Other than robots and manipulators, this category also includes automatic production lines, treatment centres, numerically controlled machine tools, and automatic welding, paint shop and assembly machines.

The progress of science and robotics-related technologies means that robots are:

- able to replace humans in hazardous or inconvenient working conditions. The work can be cyclical or irregular;

- programmable, where after completing one task the robot can be reprogrammed and retooled to perform a completely different task;

- controllable by computers and connected to other computer systems to achieve computer-integrated production.

The working environment is one of the characteristics that must be considered [ 9 , 6] when selecting an appropriate robot. In production-related fields, robots are most commonly used for transporting and handling the materials processed [14], production operations, assembly [15] and control. The use of robots in industry must be technically and economically viable for the industry [23]. Transporting materials involves the robot collecting parts from one location and moving them to another. An example of this type of application is 'pick and place', while another, more complex one is palleting [14]. In the latter case, robots have to take parts or other objects from one location and place them on a pallet or in another multi-location container.

For processing-related operations, industrial robots may be employed in heat treatment, welding, spray painting, drilling, marking out, laser cutting, riveting, grinding, brushing, and water jet cutting operations [13].

The final type of industrial robot application is assembly and control [15]. This is a combination of the two previous types, and involves both material handling and transport. Typical assembly and control applications include operations related to both materials and tools. Assembly and control are traditionally work-intensive, tedious and highly repetitive operations. For this reason, they are increasingly performed using robots.

The sectors that most commonly employ $[8 ; 23]$ robotised solutions are the automotive, electronic, electromechanical, precision, machine construction, and rubber and plastic product industries. Companies belonging to these sectors must be aware that the failure to use robots will in their case entail the loss of competitiveness and effectiveness, and consequently loss of market share.

This paper aims to analyse the level of robotisation in Poland and around the world. Factors affecting the robotisation of production processes are discussed, 
and the directions and requirements to be met by the process of robotisation are outlined.

\section{Object and Methodology of the Study}

The issues addressed in this paper are related to numerous fields of scientific research. The issue of robotisation development can be analysed from the perspective of economics, work organisation and safety, technical sciences, and ergonomics.

There are numerous factors responsible for the development of robotisation. Among the most important are the technical, economic and organisational factors. The technical factors include:

- development of precision mechanics and control systems;

- development of new material technologies;

- necessity to ensure high and uniform product quality;

- development of compact robots;

- growing demand for processes that require high precision under harmful and hazardous conditions, or on high-weight objects of complex shapes.

The economic factors are related to the need to:

- reduce operating costs;

- improve competitiveness;

- reduce energy costs;

- improve efficiency;

- reduce costs caused by short production cycles.

Within the organisation factors, the following can be defined:

- lack of workers for simple and burdensome physical jobs;

- shrinking working age population due to society ageing;

- increased work safety standards;

- developing consumer markets requiring frequent production changes and quick expansion of production capacity.

This paper first analyses the level of robotisation in selected countries. Due to Poland's location, particular attention is paid to European Union (EU) countries. As was mentioned earlier, the level and development of robotisation depend on numerous factors, with the economic factors, including labour profit and costs, being among the more notable. It was decided to use the available statistical data to study the relation between labour costs and robot saturation levels. Studying this relation should enable the determination of the position of robotisation in Poland relative to selected EU countries and outlining the potential development perspectives. The final factor taken into account, whose importance in economically developed countries grows with each year, is society ageing. 
This process leads to manpower shortages and therefore places greater pressure on the development of robotisation. This phenomenon has already been observed in many developed countries, and a similar tendency is also visible in Poland.

\section{Analysis of the Level of Robotisation in Selected Countries}

\subsection{Level of Robotisation around the World}

According to International Federation of Robotics data [8], 1.8 million industrial robots were in use worldwide by the end of 2016. In 2016, the global population of active robots increased by $12 \%$. Most of these robots were in Asian countries and Australia, where the rate of robot sales is the highest. Companies in this part of the world purchased as many as 160600 robots in 2016, which means an increase of $19 \%$ over the previous year. In terms of sales dynamics, Europe as a whole remained not only behind Asia, but also the entire American continent. For Europe, the yearly growth in sales was 12\%, with most robot sales in 2016 occurring in Germany and Italy. Robot numbers are also growing in Central and Eastern Europe, in particular in the Czech Republic, more than in Poland while having less than a third of the population. Figure 1 shows [8] the robot purchase data of the 15 largest global consumers in 2016.

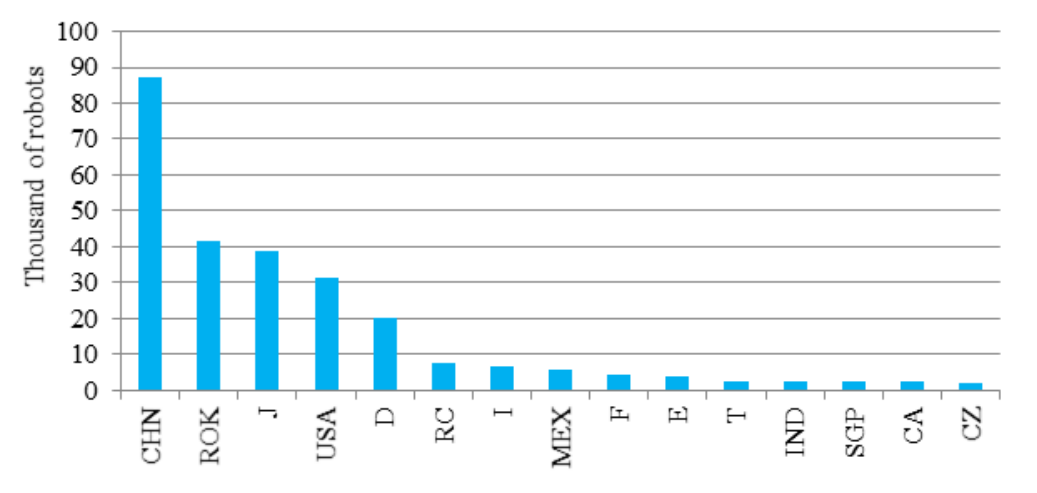

Figure 1

Robot purchases by the largest consumers in 2016 [8]

It is assumed that in 2020, 3 million robots will be in use in industry. Figure 2 shows the numbers of robots used by year, and a prediction of their use up to 2020 . 


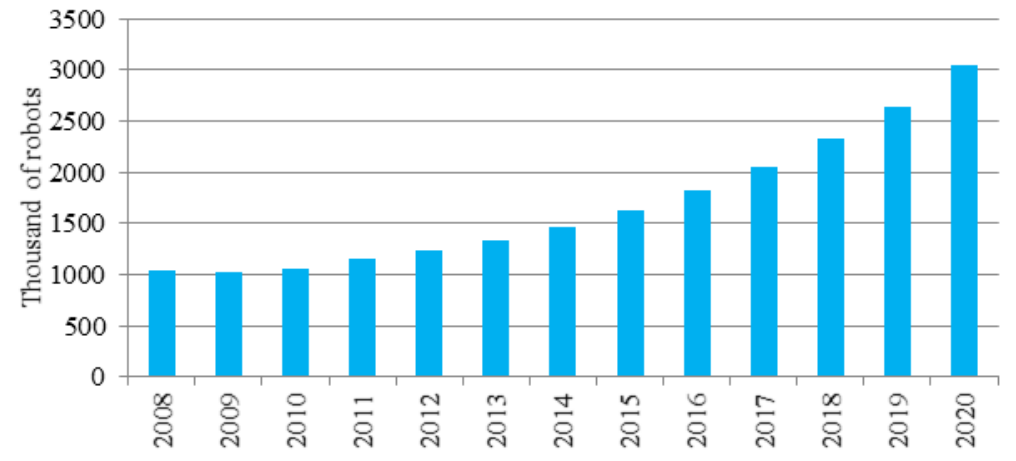

Figure 2

Numbers of robots in the economy [8]

The predicted growth in the number of robots requires the ensuring of an adequate supply. The global robot industry is prepared for this challenge, and has expanded its production capacity. The supply of robots for industrial applications, with a prediction for the years 2018-2020, is shown in Figure 3.

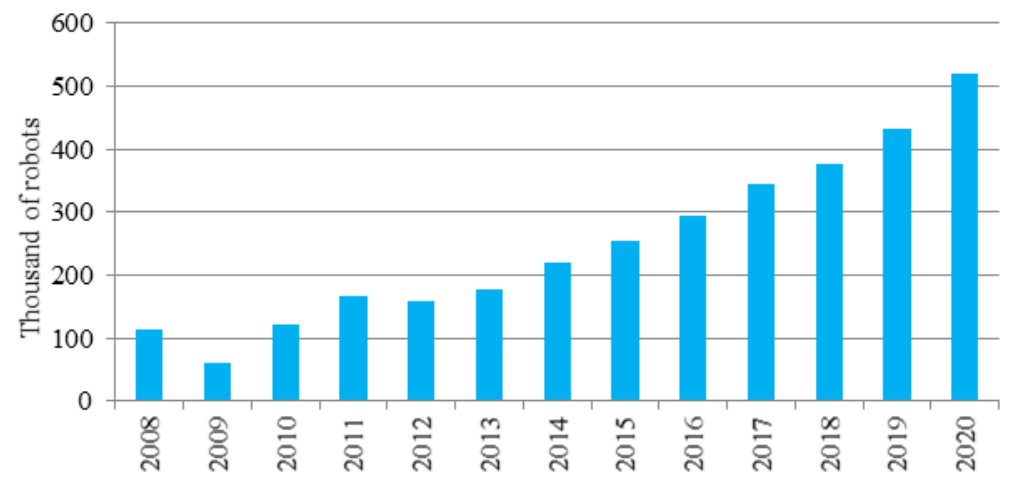

Figure 3

Supply of robots for industrial applications [8]

Due to the varying sizes of world economies, it is not useful to directly compare the numbers of installed robots. Figure 4 shows the index of robotisation density in selected countries around the world, with particular attention on Europe, calculated for the year 2016. The index is a very important parameter used to compare the degree of national robotisation. Unlike the number of installed industrial robots, the density index is a relative value and takes into account the differences in the sizes of economies. It shows the number of active industrial robots per 10 thousand people employed in industry. 


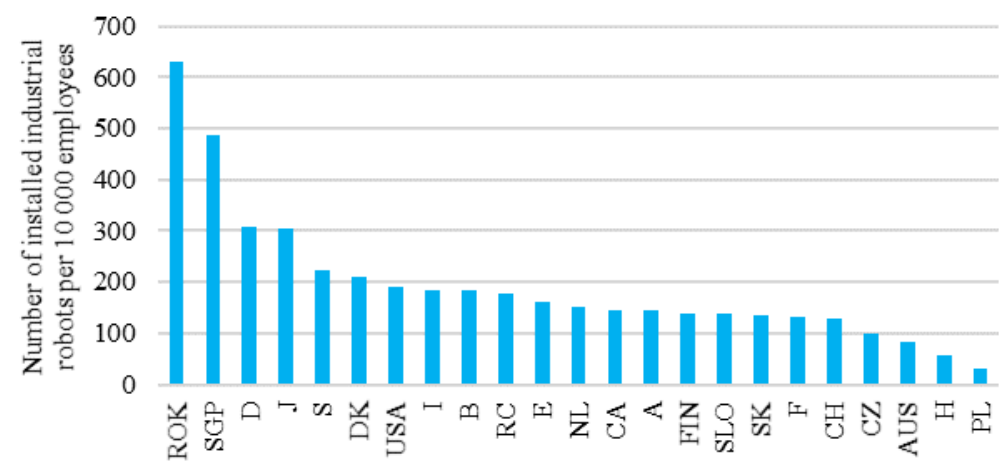

Figure 4

Robotisation density in different economies in 2016 [8]

For Poland, the value of this index was approximately 32, less than a third of the value for EU as a whole (99) and less than half the global index (74). An analysis of the data in Figure 4 indicates that Poland is at the bottom end of the European league. It is behind not only highly developed countries, but also countries at a similar level of development, such as Slovakia (135) and Hungary (57). While the robotisation density index showed a growing trend for the years 2003-2015, its growth was low compared to all of Europe or Central and Eastern European countries. The level of robotisation is also related to efficiency per worker. Figure 5 shows the labour productivity index, measured using the value of national product per worker in EU countries [16], taking into account the purchasing power standard. This chart does not differ significantly from the chart shown in Figure 4, considering only European countries.

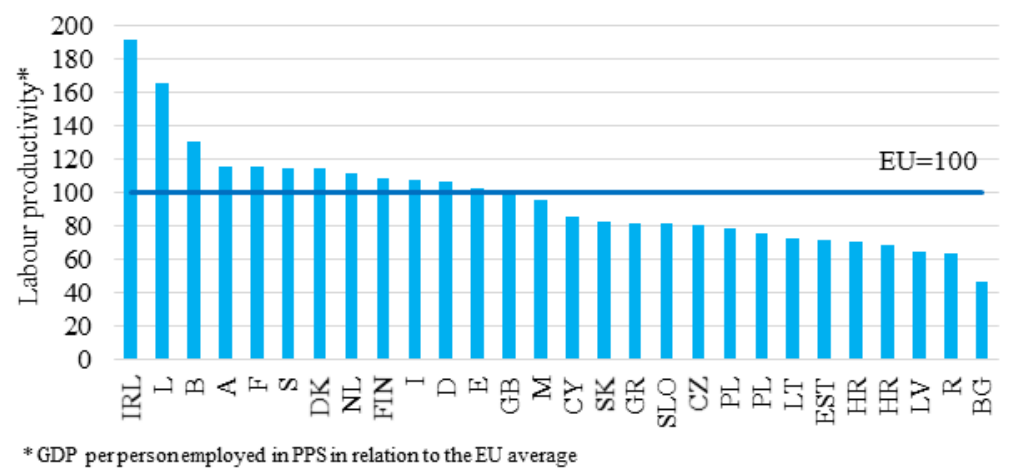

Figure 5

Labour productivity in European countries in 2016 relative to the mean [16]

Another important factor in evaluating the level of robotisation are the labour costs. Among EU countries, Poland is characterised by one of the lower labour cost values, at approx. $\$ 8 / \mathrm{h}$. A summary of these costs for EU countries is shown in Figure 6. 


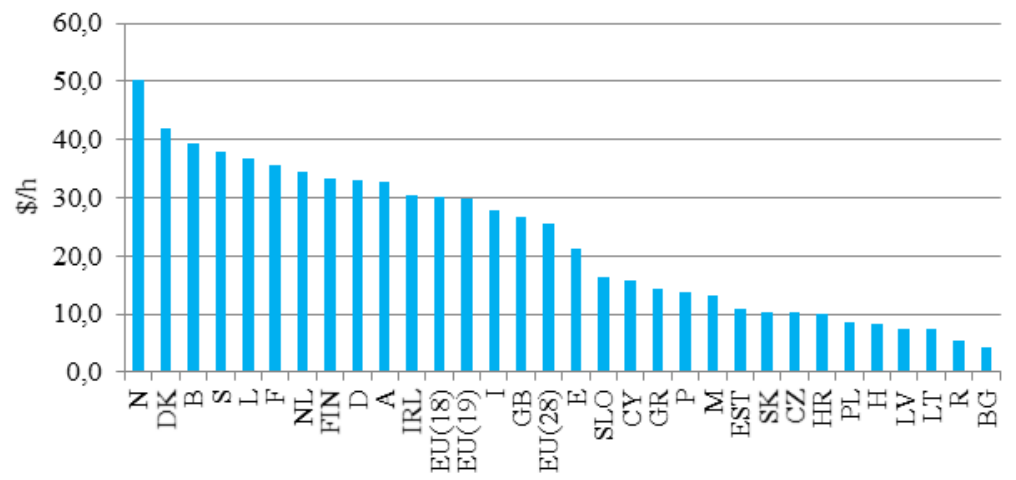

Figure 6

Costs of labour in individual EU countries in 2016 [4]

Both charts shown in Figs. 5 and 6 are similar and indicate that the GDP index and labour costs are highly related. When the costs of labour are compared with robotisation density in EU countries, an interesting relation emerges, as shown in Figure 7.

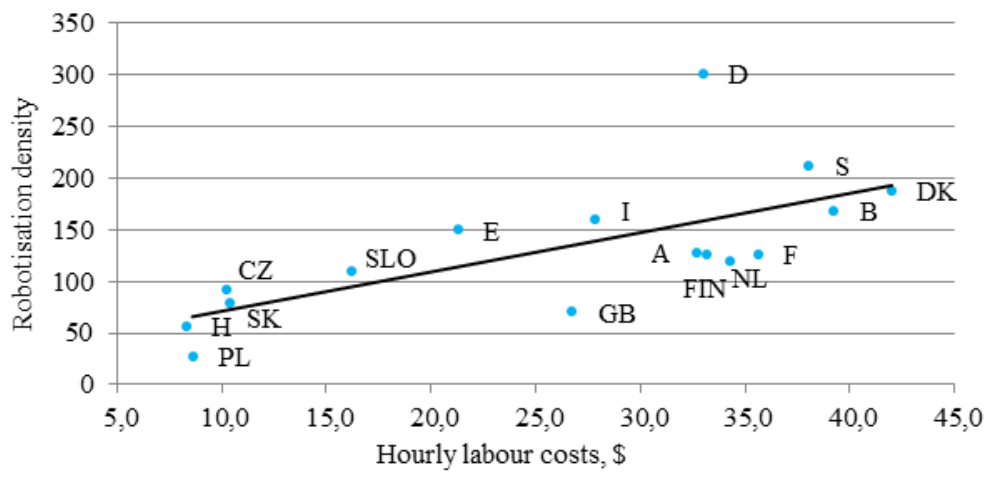

Figure 7

Robotisation density vs hourly labour cost

When analysing the above chart, it can be assumed that other than three countries - Poland, Great Britain and Germany - the relation between robotisation density and hourly labour cost is nearly linear.

\subsection{Level of Robotisation in Poland}

In 2014, robots and manipulators constituted $11.5 \%$ of the means of production process automation in industrial companies. The most robotised companies in Poland were those that manufactured means of transport [18]. They possessed more than $40 \%$ of the robots and manipulators in use in the Polish economy. 
Another group of companies, with $37.2 \%$ of the robots and manipulators, involved companies related to the manufacture of metal products, electronic and optical products, electric devices, as well machines and devices. The number of industrial robots in Polish industry is growing systematically (Fig. 8). In the years 20102015 , the number of industrial robots and manipulators increased by more than $50 \%$.

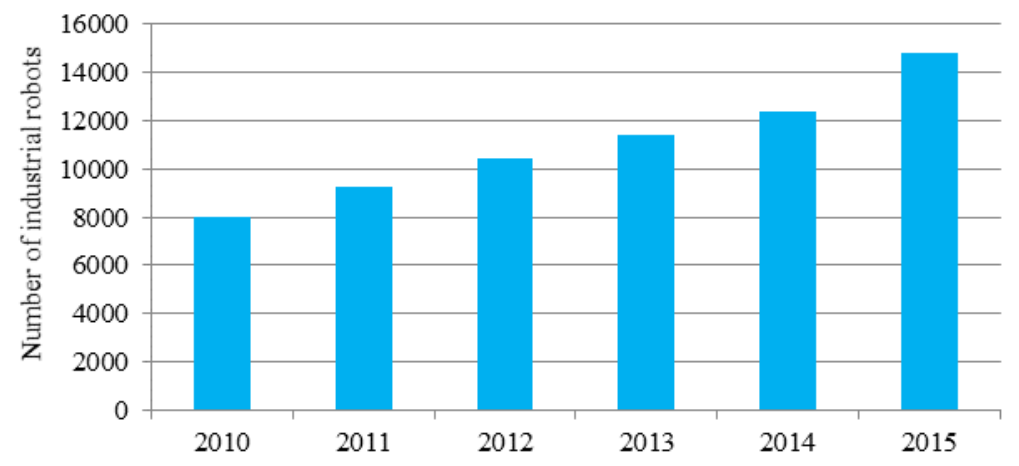

Figure 8

Number of industrial robots and manipulators in Poland (data concerning entities where the employment level exceeded 49 people) [18]

According to the International Federation of Robotics data [8], 692 robots were delivered to the Polish market in 2013, 1267 robots in 2014, and a record of 1795 in 2015. This is an increase of more than $259 \%$ over the whole period. In 2015, the number of robots and manipulators in industry was 14847 .

Considering the number of people employed in industry, most robots and manipulators were used by companies having more than 250 employees (Tab. 1). In 2014 a total of 9396 industrial robots and manipulators were used by 480 companies. In companies with 50-249 employees, the number was 2957 , used in 600 companies. In companies with 10-49 employees, the number in 2014 was 699, used in 284 companies.

Table 1

Robotisation in industry relative to the number of company employees in 2014 [18]

\begin{tabular}{|l|c|c|c|}
\cline { 2 - 4 } \multicolumn{1}{c|}{} & \multicolumn{3}{c|}{$\begin{array}{c}\text { Company size } \\
\text { (number of employees) }\end{array}$} \\
\hline Number of employees & $10-49$ & $50-249$ & 250 or more \\
\hline $\begin{array}{l}\text { Number of robots and manipulators } \\
\text { in industry }\end{array}$ & 699 & 2957 & 9396 \\
\hline $\begin{array}{l}\text { Number of companies that own } \\
\text { robots or manipulators }\end{array}$ & 284 & 600 & 480 \\
\hline
\end{tabular}


The distribution of robots and manipulators in individual voivodeships of Poland is not uniform. The disproportions in distribution are shown in Figure 9.

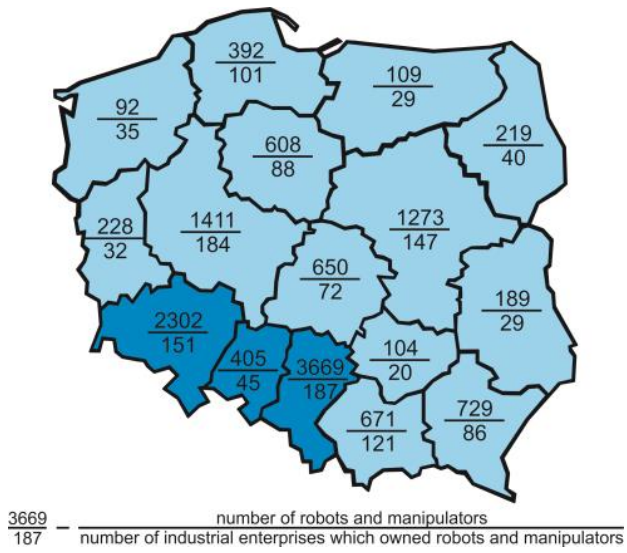

Figure 9

Distribution of robots and manipulators in individual voivodeships of Poland [18]

The descriptions for individual voivodeships concern the numbers of robots and manipulators (data above the horizontal line) and numbers of companies using these resources (below the line). Individual voivodeships differ not only in the numbers of installed robots, but also the degree of their utilisation in individual companies, as well as revenue. Data on the per capita GDP for individual voivodeships are shown in Figure 10 [5].

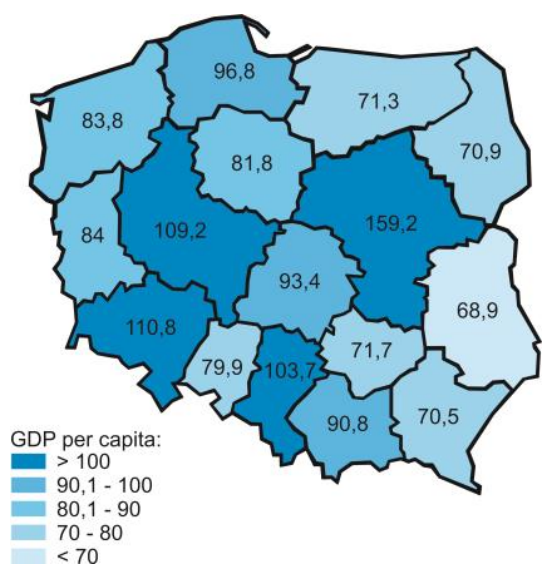

Figure 10

Data on per capita GDP for individual voivodeships [5]

The data indicate a relation between labour costs and thus income, and robotisation density in selected EU countries. In the case of Poland, at the 
voivodeship level, a similar relation between the numbers of installed robots and income can be observed by comparing Figures 9 and 10 .

The four voivodeships with the highest income exceeding national average, also have the highest numbers of installed robots and means of production automation. Each voivodeship in Poland has a different population, however. Given the above, the most beneficial would be to compare the number of robots per million inhabitants with the income achieved in the voivodeship. This comparison is shown in Figure 11.

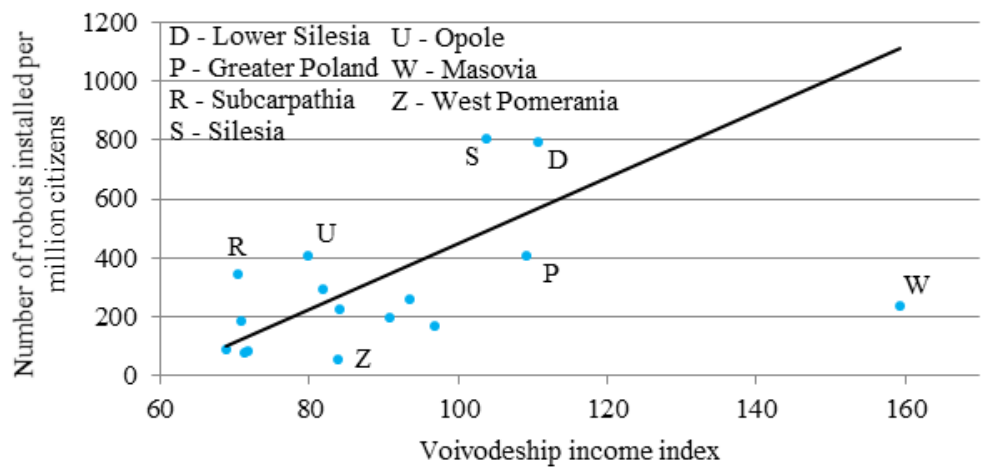

Figure 11

Relation between the number of robots installed per million inhabitants and the voivodeship income index

The relation shown in Figure 11 with a continuous line applies to 15 voivodeships. When compiling this chart, the wealthiest voivodeship Masovia, was not taken into account. The voivodeships include Warsaw, the capital of Poland, with its population of almost two million. The high income achieved by this voivodeship is to a great degree generated by governmental and financial institutions and banks with a national and international reach.

\section{Potential Factors Forcing the Growth of Robotisation in Poland}

\subsection{Economic Development of Poland}

Poland's per capita domestic product is significantly lower than the EU mean, and does not exceed $70 \%$. Improving this index requires intense economic growth, exceeding the rate of economic growth of wealthy EU countries. The changes of income in Poland, defined as per capita GDP, is shown in Figure 12 [4]. 


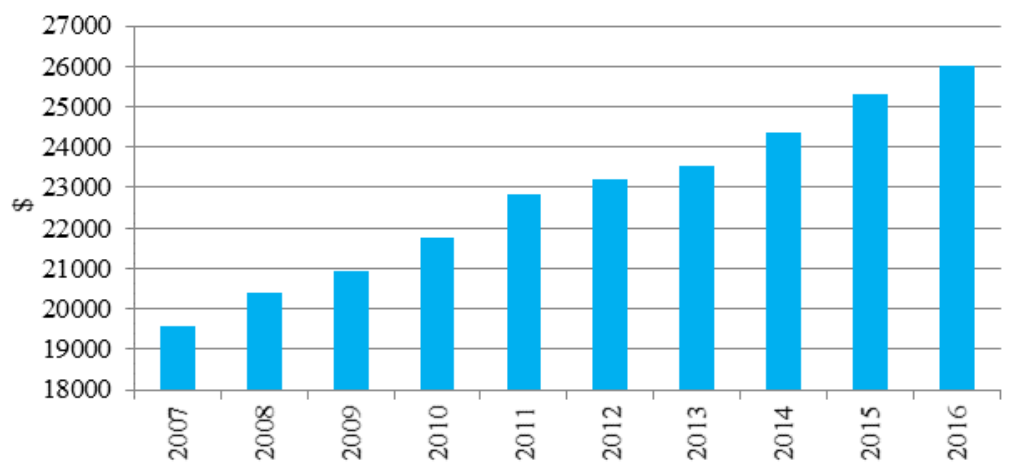

Figure 12

Poland - GDP per capita PPP [4]

One driver for this growth is industrial production. Figure 13 shows industrial production for selected years against gross national product.

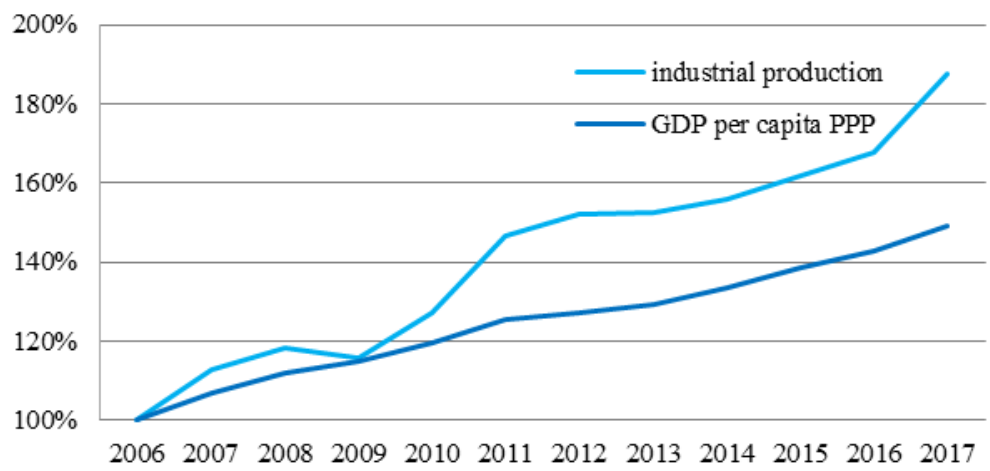

Figure 13

GDP and industrial production costs in relation to the base year [5]

An increase in GDP leads to an increase in wages. The wages for industry are shown in Figure 14. In order to ensure industry competitiveness, the increase in wages must not increase the unit labour costs. Keeping this cost at a constant level or even reducing it is possible by increasing labour productivity. See Figure 15 for productivity in selected years. 


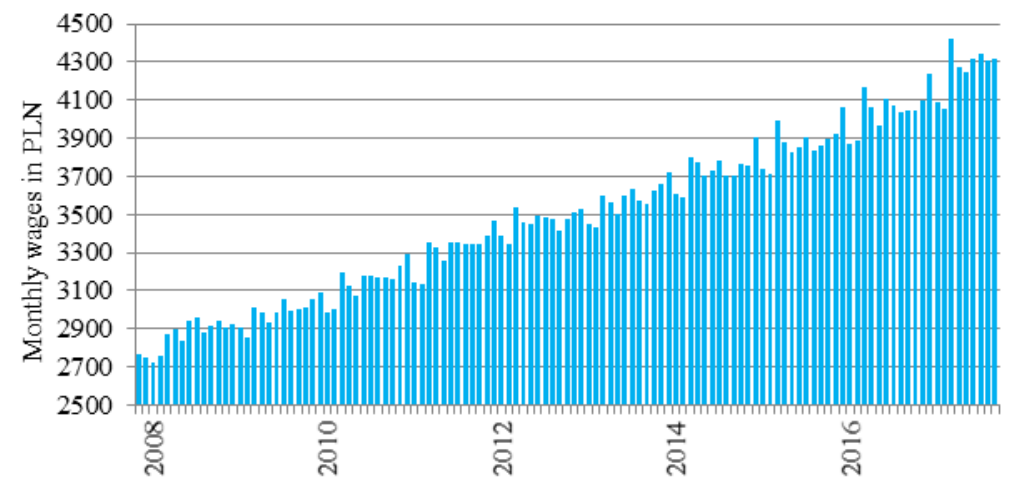

Figure 14

Poland - wages in industry [4]

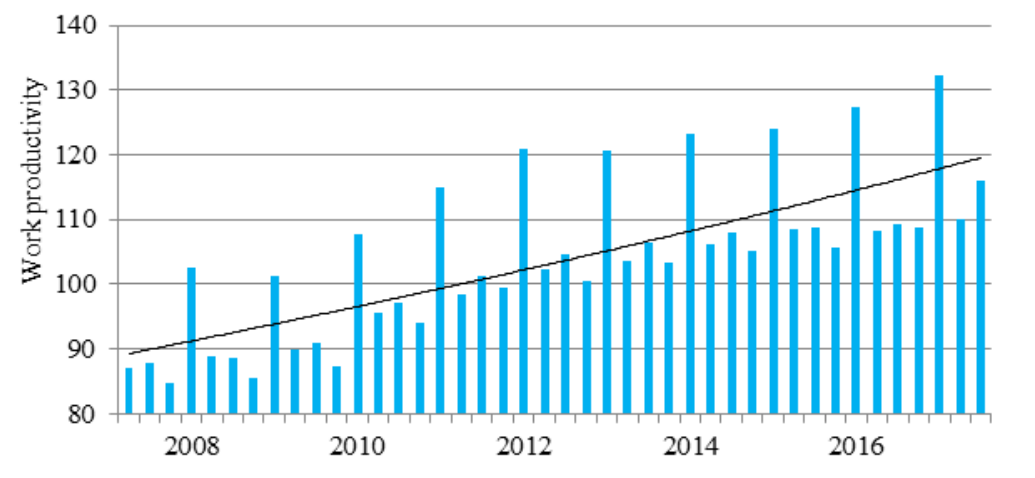

Figure 15

Poland - work productivity [4]

The unit labour costs taking into account wages and labour efficiency are shown in Figure 16. Slowing down the increase in these costs while maintaining the growth of wages was largely possible thanks to increasing the efficiency, resulting from better work organisation and improved means of production, such as industrial robots and other devices enabling greater automation of production processes. 


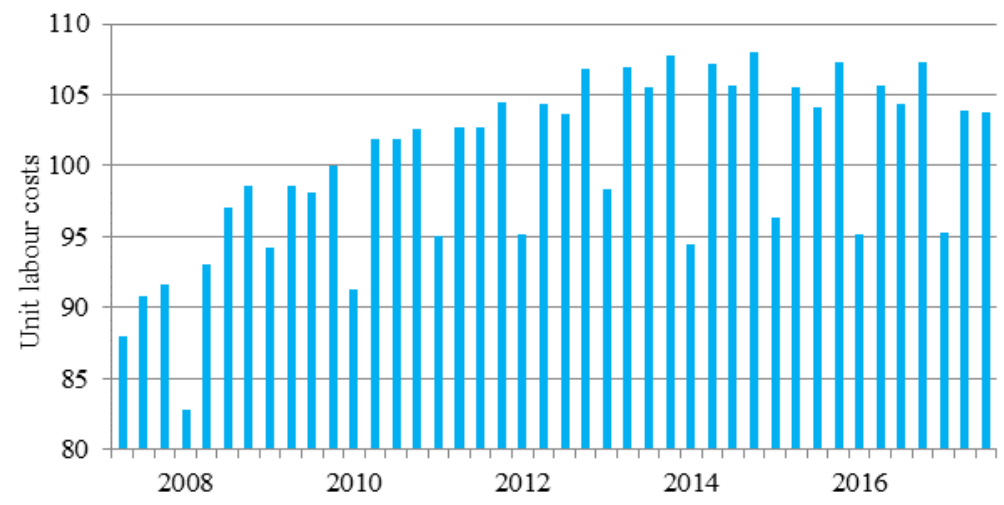

Figure 16

Poland - unit labour costs [4]

The tendency observed in Poland is consistent with global tendencies. In Poland, the dynamics of increasing robot numbers are significantly higher than the wage growth dynamics. This trend is shown in Figure 17. In the years 2010-2015, a significant increase was achieved in the use of robots and means of automation at a much lower increase in wages.

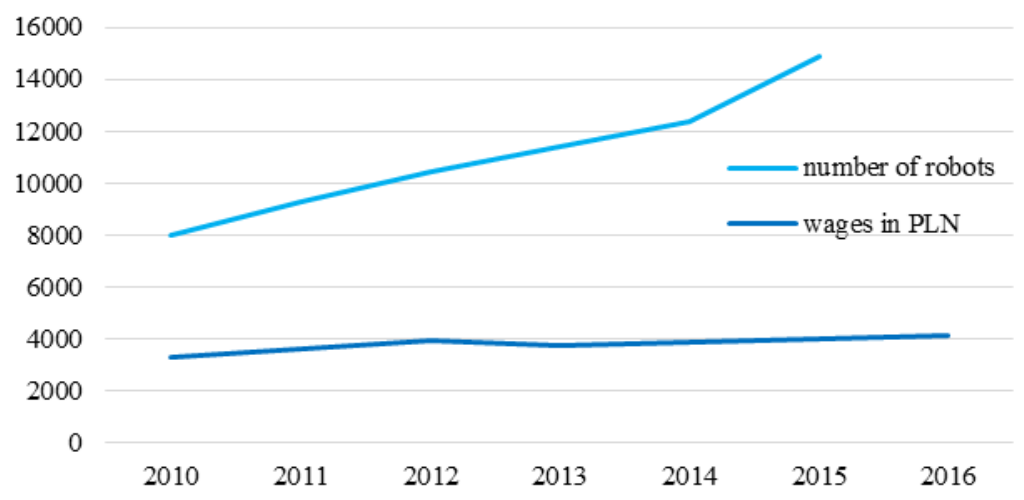

Figure 17

Growth of robot number and wage in years

According to Boston Consulting Group [19], the implementation of automated solutions will result in a global increase in productivity by approx. 10-30\% by 2025. This will also result in lower costs of labour. The greatest reduction will be observed in South Korea (33\%), Japan (25\%) and Canada (24\%), while in Poland it will only be $13 \%$. 


\subsection{Effects of Society Ageing on the Labour Market}

Until now it was profitable for Polish companies to employ new workers to achieve growth. Currently, such growth is encountering two fairly significant barriers. The first is labour costs, the second is difficulties in obtaining new employees. Robotisation is, therefore, an answer to both these issues. For several years an inexpensive, easily available and well-educated workforce was used to create an attractive business environment in Poland. However, in the coming decade, these conditions may change. The predictions [5] for 2050 show a great reduction in the size of the working age population. This prediction is shown in Figure 18.

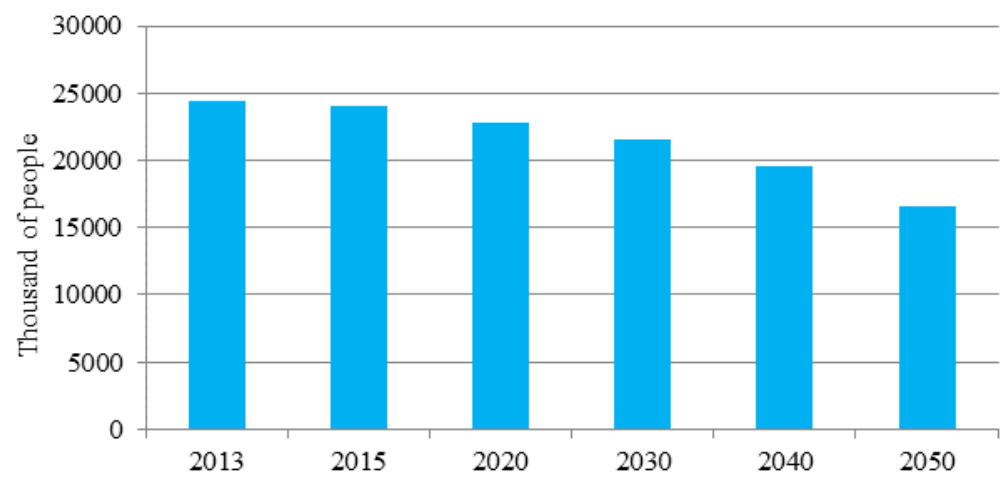

Figure 18

Numbers of working age population [5]

It is estimated that in the immediate future, until 2025, the size of the working age population will dwindle by as much as 2.6 million people. Some of this loss can be replaced by immigrants and some by transfers between individual industries. However, these effects are unlikely to fully satisfy the needs of the labour market. To ensure an adequate level of production and growth, a sufficient number of robots will have to be installed. This is an important factor indicating a need for companies to invest in the purchase of robots. With the aging of society, the ratio of professionally inactive people to working age people also changes. In Poland, the ratio of these two groups is approximately 0.75 today, and will increase to 1 within 15 years, and over the following fifteen years will increase to 1.4. All simple, burdensome and tedious jobs must therefore become automated. An aging society will not be interested in performing simple, burdensome and tedious jobs.

\section{Conclusions}

The development of robotisation processes is a global trend. The presence of this tendency is also visible in Poland. In many cases, robotisation contributes to lowering the costs of production, increasing the flexibility of production lines, and 
enabling humans to be replaced by robots in repetitive and frequently hazardous jobs. However, this process frequently requires fairly significant financial investments, and especially a change in how a company is managed. Thanks to the progress in technology, the capabilities of robots improve with every passing year, and thus forms one of the cornerstones of economic growth. Compared to selected countries around the world and the EU, the level of robotisation in Poland is low. Poland is exceeded in this field by its immediate neighbours in the EU. In the group of countries with similar labour costs, such as Hungary, Slovakia and Czech Republic, Poland is characterised by the lowest level of robotisation. Due to limited manpower, Poland's further development without investments in robotisation becomes problematic, and therefore investments intended to develop robotisation and automation become a necessity. Despite the high dynamics of growth in industrial robot purchase and installation, the situation for the next few years is unlikely to improve significantly, thus reaching the average EU level will take many years. The process is inevitable, however, as without it the competitiveness level of Polish companies will degrade and, in many cases, manpower shortages caused by society ageing will result in production reduction.

\section{References}

[1] Day C.-P.: Robotics in Industry-Their Role in Intelligent Manufacturing, Engineering 4 (2018), pp. 440-445

[2] Geren N, Redford A.: Cost and performance analysis of a robotic rework cel, Int. J. Production Economics 58 (1999), pp. 159-172

[3] Global Industrial Robotics Market Overview Infographic https://www.robotics.org/blog-article.cfm/

[4] https://tradingeconomics.com

[5] http://swaid.stat.gov.pl

[6] Iglesias I., Sebastián M. A., Ares J. E.: Overview of the state of robotic machining: Current situation and future potential, Procedia Engineering 132 (2015), pp. 911-917

[7] Industries and Economies Leading the Robotics Revolution. The Boston Consulting Group https://www.bcg.com/publications/2015/leanmanufacturing-innovation-industries-economies-leading-roboticsrevolution.aspx

[8] International Federation of Robotics https://ifr.org/

[9] Kamble S. S., Gunasekaran A., Sharma R.: Analysis of the driving and dependence power of barriers to adopt industry 4.0 in Indian manufacturing industry, Computers in Industry 101 (2018), pp. 10-119

[10] Khana Z. H., Khalidb A., Iqbalc J.: Towards realizing robotic potential in future intelligent food manufacturing systems, Innovative Food Science and Emerging Technologies 48 (2018), pp. 11-24 
[11] Kosea T., Sakatab I.: Identifying technology convergence in the field of robotics research, Technological Forecasting \& Social Change, Article in Press

[12] Landscheidta S., Kansb M.: Method for Assessing the Total Cost of Ownership of Industrial Robots, Procedia CIRP, Volume 57, 2016, pp. 746751, DOI: doi.org/10.1016/j.procir.2016.11.129

[13] Landscheidta S., Kansb M., Winrothc M. Westerd H.: The future of industrial robot business: Product or performance based? Procedia Manufacturing, Volume 25, 2018, pp. 495-502, DOI: doi.org/10.1016/j.promfg.2018.06.125

[14] Mahalik N. P.: Processing and packaging automation systems: a review, Sens. \& Instrumen. Food Qual. (2009) 3, pp. 12-25, DOI: 10.1007/s11694009-9076-2

[15] Michels A. S., Lopes T. C., Stall Sikora C. G., Magatão L.: The Robotic Assembly Line Design (RALD) problem: Model and case studies with practical extensions, Computers \& Industrial Engineering 120 (2018), pp. 320-333

[16] Poland in the European Union. Warsaw 23.07.2018. http://stat.gov.pl/en/topics/other-studies/other-aggregated-studies/polandin-the-european-union-2018,10,12.html

[17] Povolná, L., Švarcová, J. (2017) The Macroeconomic Context of Investments in the Field of Machine Tools in the Czech Republic. Journal of Competitiveness, Vol. 9, Issue 2, pp. 110-122

[18] Science and technology in 2014. Warsaw 2015. http://stat.gov.pl/obszarytematyczne/nauka-i-technika-spoleczenstwo-informacyjne/

[19] Takeoff in Robotics Will Power the Next Productivity Surge in Manufacturing. The Boston Consulting Group https://www.bcg.com/d/press/10feb2015-robotics-power-productivitysurge-manufacturing-838

[20] Tuček, D. (2016) Process Segmentation Typology in Czech Companies. Journal of Competitiveness, Vol. 8, Issue 1, pp. 79-94

[21] Ungerman, O., Dedkova, J., Gurinova, K.: The Impact of Marketing Innovation on the Competitiveness of Enterprises in the Context of Industry 4.0. Journal of Competitiveness, Vol. 10, Issue 2, pp. 132-148, June 2018

[22] Zhang J. Fang X., Qi L.: Sensitivity-analysis based method in single-robot cells cost-effective design and optimization, Roboticsand ComputerIntegrated Manufacturing 38 (2016) pp. 9-15

[23] Zwicker C., Hammerstingl V., Possin C, Reinhart G.: Life Cycle Cost Estimation Of Robot Systems in an Early Production Planning Phase, Procedia CIRP 44 (2016) pp. 322-327 